character relied on has been the production of a nonsuppurative polyarthritis and endocarditis in rabbits. Now animal experiment, uncontrolled by other means of research, may be a very dangerous guide. Even the specificity of these "specific" effects upon the rabbit is unproven. There is at least a certain amount of evidence (e.g., the experi. ments of Menzer and of Cole) that arthritis, endocarditis, and pericarditis of more or less "rheumatic" character may be produced in rabbits by the injection of strcptococci from totally non-rheumatic sources, even from the normal throat. We cannot find that Dr. Poynton and Dr. Paine have controlled their results by any extended experiments of this sort. In those in which they used streptococcus pyogenes the rabbits naturally died from acute septicæmia.

Should it be confirmed that the "diplococcus rheumaticus" is identical with one or more of the common saprophytic cocci of the alimentary canal we believe that a name indicative of such a source would be preferable to one implying a specific connexion with a disease where such specificity is at least doubtful. The bacteriology of rheumatic fever has been so ably and so fairly dealt with by Dr. Balloch in the recently issued second volume of Allbutt's "System of Medicine" that there is no occasion to discuss it further here. We are in perfect agreement with the conclusions to which Dr. Bulloch has been led. We regret that our reference to the decease of the culture sent us by Dr. Paine should have given offence. Streptococci not rarely die in the post and we intended no suggestion that it was not alive when sent off.

We are, Sirs, yours faithfully,

F. W. ANDREWES,

THOMAS J. HORDER.

St. Bartholomew's Hospital, Dec. 3rd, 1906.

\section{THE BACTERIOLOGY OF ASEPTIC WOUNDS.}

To the Editors of THE LANCET.

SiRs, - In the debate at the Medical Society on Oct. 22nd, 1906, I said that I had difficulty in following the reasoning of Mr. L. S. Dudgeon and Mr. Percy Sargent regarding the bacteriology of aseptic wounds. I urged that if the staphylococcus albus was regarded by them as necessary to healing it should be found in all cases. In reply, Mr. Sargent suggested that my difficulty arose from the extreme simplicity of the views advanced, and, if I understood him aright, he held that although staphylococci were not always found it did not follow that they were not always present.

With the whole paper before me in THE LANCET of Nov. 17th I should like to be allowed to draw attention to certain points which seem to require explanation. The authors have confirmed the observations of Professor Welch and others that a white staphylococcus shows a very great facility for getting into wounds, and they seem to consider its presence useful, if not essential, to healing. Professor Welch taught that this coccus was harmful although its powers for mischief were small, and his teaching seems to me to be the more in accord with the evidence. I cannot understand from the paper read at the Medical Society how far Mr. Dudgeon and Mr. Sargent agree with Professor Welch on this point. They speak of the staphylococcus albus as an organism of very low virulence. Again, they describe an aseptic wound as one "which heals by first intention, exhibits no naked-eye evidences of inflammation, and causes no constitutional disturbance." But in all the cases in which the wounds were described as aseptic ther was "a pyrexia of from $99^{\circ}$ to $100^{\circ} \mathrm{F}$. for two or three days after the operation." This phenomenon, which surely was a constitutional disturbance, was attributed to the presence of the staphylococcus albus, and thus that organism seemed to induce one of the indications of septic action as defined by the authors.

I have from time to time combated the idea that microorganisms are essential to inflammation, in which view I am definitely supported by the teaching of Lord Lister. Recently I argued that there is no hard-and-fast line between inflammation and physiological action or between various forms of inflammation. ${ }^{1}$ In this I followed the teaching of Professor Adami, and since my paper was written he has

1 Inflammation and Peritonitis considered as Physiological Processes, Transactions of the Royal Medical and Chirurgical Society, vol. lxxxix. published a most interesting and instructive account of all the most recent researches connected with the inflammatory process, in which he stated that " the attempt to mark off sharply the inflammations caused by mechanical and chemical noxe from those produced by bacteria and their products must be given up." '2 It seems to me that the facts brought forward by Mr. Dudgeon and Mr. Sargent fali perfectly into line with this view. They have shown that a white staphylococcus - an organism of very low virulence - when injected into the peritoneal cavity induces an exudation rich in leucocytes. This is clearly an effect of irritation. Experimentally it has been shown that when this exudation has been produced the animal is able to survive the injection of a dose of colon bacilli which would inevitably prove fatal without the preliminary action of the staphylococci.

The explanation given by Mr. Dudgeon and Mr. Sargent, as I understand, is that the staphylococcus albus exercises a protective action as regards the peritoneum. Thus far their point is proved in the laboratory. But at the bedside we know that, in a case of gangrenous appendicitis, for example, there frequently is an exudation rich in leucocytes induced, I have no doubt, by a staphylococcus. Up to a certain point the patient is fairly safe with this fluid in the peritoneal sac. But if operative interference is delayed and pyogenic bacteria enter the belly cavity, these are mixed with the fluid and distributed all over the peritoneum. causing a widespread suppurative peritonitis. It is obvious that as these last changes take place the serum exuded in response to the milder irritant is not in any way useful to the animal economy or protective to the peritoneum. On the other hand, if a pyogenic organism enters the peritoneal cavity alone, adhesions and a localised abscess probably develop, in which case the protective poner of suppuration. which Professor Welch laid much stress upon, is illustrated.

A very important point brought out by $\mathrm{Mr}$. Dudgeon and $\mathrm{Mr}$. Sargent in their interesting and instructive investigations is that the micro-organisms which most readily gain access to the tissues and which it is most difficult to keep out of wounds are among the least pathogenic. That their presence is desirable or useful seems to me, however, quite unproved, unless it be in the sense that, when means of communication were primitive, the scouts of an invading force might be considered useful to the inhabitants of an invaded territory by warning them and giving them time to prepare for a more serious attack. But that these scouts could be considered friendly or welcome can hardly be maintained, and in the same way it seems to me that starhylococci are undesirable in a wound. Hence every care should be taken to exclude all micro-organisms and the tables published by Mr. Dudgeon and Mr. Sargent seem to show that their exclusion was most effectually accomplished when chemical germicides were judiciously used.--I am, Sirs, yours faithfully,

Portman-street, W., Nov. 24th, $1906 . \quad$ JOHN D. MALCOlM

\section{WARDS FOR THE OBSERVATION AND TREATMENT OF TEMPORARY MENTAL DISORDER IN GENERAL HOSPITALS.}

To the Editors of THE LANCET.

SrRs, - In your leading article on this subject in THE LANCET of Dec. 1st, p. 1525, you refer with appreciation to the work achieved in the mental wards of the infirmaries of London. I bave the figures for 1905 before me, showing that out of 7322 cases admitted, 2877 were discharged cured and 3583 were sent to asylums. I emphatically endorse your view, that treatment is needed in the early stages of the disease, during which it is perfectly obvious to the patients and their friends that the mental balance is disturbed, but in which period no efficient help is forthcoming. The present system of preliminary detention in infirmaries saves nearly 3000 cases annually from being unnecessarily stigmatised as lunatics, but, together with the grandiose and enormously expensive scheme of the London County Council, which would brand all its detained cases as lunatics, it has no provision for dealing with mental disease until the symptoms are sufficiently obvious to render certication the only safe procedure. Your suggestion meets a 
real and urgent need and it is hoped that the hospital authorities of London will see their way to its adoption.

I am, Sirs, yours faithfully,

F. S. Toogood, M.D. Lond

Barrister-at-Law ; Medical Superintendent, Lewisham

Lew isham, S. W., Dec. 1st, 1906

Infirmary.

\section{MORAU AND "JENSEN'S TUMOUR."}

To the Editors of TIIE LANCET.

SIR, - I have never claimed the Walker prize for Morau but I do maintain that he is the discoverer and original investigator of the malady improperly called "Jensen's Tumour," of which there are many different histological trpes, none of which have any real similitude to human cancer, as I have elsewhere indicated. The "confusion and inaccuracy " to which Mr. Morris has alluded 'are not in my writings.

I am, Sirs, yours faithfully,

Clifton, Bristol, Dec. 3rd, 1906.

W. ROger Williajis.

\section{THE ADMISSION OF WOMEN TO THE DIPLOMAS OF THE ROYAL COLLEGE OF SURGEONS OF ENGLAND.}

To the Editors of THE LANCET.

SIRS, - I have always been one of those who contend that women should, if they wish, consult advisers of their own sex and that those who wish to enter the profession should have an opportunity of passing the requisite examinations. These conditions are now established. It would be a misfortune, alike for the profession and for the College, if it were to dissociate itself from the interests of an everincreasing section of the profession, and I can only hope that a majority of the Fellows and Members of the Royal College of Surgeons will urge the Council to take its share in admitting the fit and rejecting the unfit candidates of both sexes for its diploma.-I am, Sirs, yours faithfully,

Eastbourne, Nov. 26th, 1906.

$$
\text { J. TINCENT BeLL, F.R.C.S. Eng. }
$$

\section{THE ACIDITY OF THE URINE.}

To the Editors of THE LANCET.

SIRS,-In THE LANCET of Nov. 17th, p. 1381, appeared a notice of a translation by A. X. Starros, D.Sc., of Joulie's method of examination of the urine and theory of the acidity of the blood. It was in May last that I first became acquainted with the Joulie method, and, as the theory underlying it seemed so reasonable, I commenced at once to test its usefulness in my own practice. The first case selected was one of chronic psoriasis, accompanied by an unusual amount of itching. For many years the patient had adopted well-known lines of treatment but had never received so much benefit as she noticed definitely and at once after fullowing internal treatment along the lines of the suggestions resulting from the Joulie analysis of the urine. The eruption disappeared in a few weeks and so far there has not been any relapse-i.e., for six months. It would occupy far too much space if I were to attempt to report, even in brief, the interesting information gathered from these examinations of the urines of patients suffering from such diseases as psoriasis, eczema, urticaria, "ungluing" of the nails, universal dermatitis (such as pityriasis rubra), and some of the chronic, specially pruriginous, affections, such as praritus ani. It is well known how sad the sufferings often are in the last-named rebellious ailment. My experience in one of these cases is worth recording here. It was that of a lady who had suffered for many years a little; for five years off and on, severely; and at the time when I first saw her she was in a very bad state notwithstanding that she could well afford and had kept up continuous medical treatment in many places. She was improving under my treatment of soothing applications, and her urine was no longer alkaline, as it had been when she first came to me. Almost certainly this alkalinity had been due to the alkalies which had been ordered previously. Thinking the case one about which I should almost certainly gain valuable information from the Joulie analysis, I gave her, by way of preparation, as few drugs as possible. The result was even better than I could have expected. The treatment suggested was adopted and within the first 24 hours the patient felt better. Night draughts which had been hitherto necessary to obtain sleep were given up. Her rapid and continuous improvement soon enabled the lady to return to her home in the country in July last. 'T'wo weeks ago she wrote gratefully saying there had been no relapse. Such a result in such a case must mean that there is something in this method which is too important to be ignored. Possibly much may yet have to be explained and modified with time, but I feel sure the method has come to stay. Already it promises to lessen the excessive employment of alkalies in the treatment of dyspepsias and gouty conditions. For many years, tharks to the teaching of my own father, I have been fully aware of the advantages of giving the citrates instead of the bicarbonates of soda or potash in certain gouty conditions, but it was new to me to find that in phosphoric acid and phosphate of soda, used as part of the Joulie method. that we had such a powerful means of correcting certain faulty conditions of the bloud. Given a case of indefinite or suspected gout not answering well to ordinary alkaline or acid prescriptions, such a case will almost certainly repay well the trouble and expense of obtaining a Joulie analysis together with the suggestions always accompanying the report from the analytical chemist.

I am, Sirs, yours faithfully,

Wimpole-street, W., Nov. 28th, $1906 . \quad$ ALFRED EDDOWES.

\section{SPLENOMEGALIC POLYCYTHAMIA. To the Editors of THE LANCET.}

Sirs, --In The Lancet of Nov. 24th, p. 1433, Dr. F. Parkes Weber attributes to Professor Osler the credit of describing as a "clinical entity" the condition now known as splenomegalic polycythæmia. I venture to point out that even these words are taken from a preliminary note to a paper on the same subject written by myself a year and a half before Professor Osler's. In THE LANCE' of Feb. 22nd, 1902, p. 515, I published a paper entitled "An Unexplained Condition of Chronic Cyanosis," in which, by the kind permission of Dr. Saundby, I recorded the first case of the sort which had been published in England. My paper also contained abstracts of three similar cases which had been reported in American journals and concluded with a comparison of the four cases and an enumeration of the features, including polycythæmia, common to them all. It was inserted under the Mirror of Hospital Practice; but in a prefatory note written by yourselves you were good enough to make use of the following words : "The disease affecting the following case and the three other cases the records of which have been discovered by Dr. Russell, is evidently a definite clinical entity and one which is new to medical science." Professor Osler's paper was published in August, 1903, and contained four original observations, together with abstracts of the four cases dealt with in $\mathrm{my}$ paper and of Yaquez's case, the existence of which was unknown to me. Its opening sentence is as follows: "The group of cases here reported, with those collected from the literature, are worthy of careful study, as we have here in all probability 'a definite clinical entity and one which is new to medical science,' to use the words of Saunoby and Russell in describing their case." This is, of course, incorrect, as the expression was used by the Editors of THE LANCET to summarise my conclusions. Professor Osler's name will always be so prominently associated with the condition that I feel sure that I need not apologise for making this statement.

I am, Sirs, yours faithfully,

Birmingham, Nov. 26th, 1906.

JAMES W. RUSSELL.

\section{THE PATHOLOGY OF SCIATICA. \\ To the Editors of THE LANCET.}

SIRs,-Having seen only one-fifth (500 as against 2500 cases), I cannot set my views as to the real nature and pathc logy of sciatica-and, let me add, of neuritis of the upper arm-against those of Dr. Béla Bosínyi of Budapest. Fortunately, we do not really differ. I have never said that in every instance there is invariably present hip trouble in that complaint; I merely wished to point out such has been my own experience. I may very likely be influenced by 